\title{
Sosyal Medya Haberlerine Güven ve Kullanıcı Teyit Alışkanlıkları Üzerine Bir İnceleme
}

\author{
Mehmet Fatih Çömlekçi \\ Öğr. Gör. Dr., Kırklareli Üniversitesi \\ Dış İlişkiler Koordinatörlüğü \\ fatihcomlekci@gmail.com \\ ORCID: 0000-0002-4811-5558
}

\section{Oğuz Başol}

\begin{abstract}
Doç. Dr., Kırklareli Üniversitesi, İktisadi ve İdari Bilimler Fakültesi
Çalışma Ekonomisi ve Endüstri ilişkileri Bölümü

oguzbasol@klu.edu.tr

ORCID: 0000-0002-7523-4544
\end{abstract}

\section{Abstract \\ Research on social media news trust and news verifica- tion awareness}

This study aims to design a tool for measuring social media users' levels of social media news trust and news verification awareness, to investigate if there is a significant difference between the trust towards news produced by professional journalists and individuals' news production/shares, and to examine whether social media users check the trueness of social media news before they share them. To that end, a survey was conducted with the participation of 763 university students and following the analysis of the results, a 3-factor structure as "verification", "trust on professional social media shares" and "individual social media shares" was proven to be a valid and reliable scale for university students. Also, it has been observed that the trust of participants towards professional channels is higher than the individual shares and the youth, who use social media to get news have higher levels of news verification awareness.

Keywords: Social media, Social media verification, Social media trust, Exploratory factor analysis, Confirmatory factor analysi 


\section{Résumé}

Une étude sur la confiance envers les informations diffusées via les médias sociaux et les habitudes de vérification des utilisateurs

Cette étude a pour objectif de concevoir un instrument pour mesurer le niveau de vérification et de confiance des utilisateurs envers les informations provenant de différents canaux de médias sociaux. Aussi elle cherche à questionner s'il existe une différence significative entre les niveaux de confiance envers les informations diffusées par des journalistes professionnels et celles qui sont produites ou partagées par des utilisateurs sur les médias sociaux et d'analyser dans quelle mesure les utilisateurs font des recherches pour vérifier les informations qu'ils reçoivent via les médias sociaux avant de les partager. Suite à une étude réalisée auprès de 763 étudiants, on a constaté que la structure à 3 facteurs comprenant les thèmes de "la vérification", de "la confiance accordée aux partages sur les médias sociaux institutionnels" et de "la confiance accordée aux partages sur les médias sociaux individuels" est une échelle fiable et valide pour les étudiants. En outre, on a obtenu comme résultat que les utilisateurs font plus confiance aux canaux institutionnels, en comparaison aux partages individuels et ceux qui utilisent les médias sociaux pour avoir des informations ont un réflexe de vérification à un niveau élevé.

Mots-clés: médias sociaux, médias sociaux vérification, médias sociaux confiance, analyse factorielle explicative, analyse factorielle confirmatoire

\section{Öz}

Mevcut çalışma, kullanıcıların sosyal medya üzerindeki farklı mecralardan aldıkları haberlere olan teyit/güven düzeylerinin ölçülmesi için bir araç tasarlamayı, profesyonel gazeteciler tarafından üretilen haberlerle, kullanıcıların ürettiğı ya da paylaştığı sosyal medya haberlerine güven arasında anlamlı bir farklılı olup olmadığını ve kullanıcıların sosyal medyada karşılaştıkları haberleri paylaşmadan önce ne ölçüde araştırma yaptıklarını incelemeyi amaçlamaktadır. 763 üniversite öğrencisinin katıımıla bir araştırma gerçekleştirilmiştir ve yapılan analiz sonrasında "teyit", "kurumsal sosyal medya paylaşımlarına güven" ve "bireysel sosyal medya paylaşımlarına güven" başlıklı 3 faktörlü bir yapının öğrenciler için geçerli ve güvenilir bir ölçek olduğu görülmüştür. Ayrıca katılımcıların, kurumsal mecralara, bireysel paylaşımlara kıyasla daha fazla güvendikleri ve sosyal medyayı haber alma amacıyla kullananların teyit etme reflekslerinin yüksek olduğu sonucu elde edilmiştir.

Anahtar Kelimeler: Sosyal medya, Sosyal medya teyit, Sosyal medya güven, Açıklayıcı faktör analizı, Doğrulayıcı faktör analizı

\section{Giriş ve Kavramsal Çerçeve}

Yeni iletişim teknolojilerinin damgasını vurduğu günümüz toplumunda, Internet ve sosyal medya, enformasyonun hızı bir biçimde dolaşımını sağlamakta, sosyo-ekonomik değişimleri tetiklemekte ve kişilerarası iletişimi olduğu kadar medya ile habercilik anlayışını da dönüşüme uğratmaktadır. İnternet 21. yüzyılla birlikte fiziksel sınırları aşarak insanları küresel ağlar üzerinde bir araya getirmeye başlamış (Castells ve Cardoso, 2006, s. 4), web 2.0 olarak adlandırılan süreçle birlikte ise tek yönlü iletişim döngüsü kırılmış, içerik ve uygulamalar sadece profesyoneller tarafından değil, sürekli olarak tüm kullanıcılar tarafından katılımcı bir modelle üretilmeye başlanmıştır (Kaplan ve Haenlein, 2010, s. 61). Sosyal medya ise çok farklı etkileşim biçimlerini ortaya çıkararak (Hansen vd., 2011), platformlar aracıllı̆ııla çevrimiçinde bağlantısal bir kültür oluşumuna neden olmuş (Van Dijk, 2013, ss. 8-9); kullanıcıların içerik üretmekle kalmayıp birbirleriyle ve platformlarla sürekli olarak etkileşime girdikleri çok yönlü bir iletişim modelini mümkün kılmıştır.

Tüm bu gelișmeler habercilik ve gazetecilik pratiklerini de derinden etkilemiştir. İnternet'le birlikte yayılmaya başlayan bloglar, Facebook ve Twitter gibi sosyal medya uygulamaları ile geçmişte pasif birer tüketici konumundaki kullanıcılar diğer kullanıcılarla etkileşime girerek ortaklaşa içerik üretmeye, kendi haberlerini yapmaya ve ağ üzerinde bunları yaymaya/paylaşmaya başlamışlardır. Bu anlamda profesyonel gazetecilik de bir dönüşüm yaşamış, ana-akım medya kuruluşları da sosyal medyanın hikaye anlatıcılığına kattığı interaktif ve multimedya özelliklerden (video, fotoğraf, yorum, vb.), daha genis kitlelere ulaşabilme ve gündeme hızlı reaksiyon verebilme imkanlarından faydalanmaya başlamışlardır (Newman, 2009). Ana-akım medya internet ortamının etkileşime dayanan yapısına ayak uydurmaya çalışırken haber üretimi süreci de profesyonel gazetecilerin tekelinden çıkmış; bilgiye ulaşımın kolaylaşmasıyla birlikte vatandaşların ve toplulukların alternatif medya girişimleri çok sesliliğe ve iletişimin ortamının demokratikleşmesine katkı sunmuştur (Rodriguez, 2008; Atton, 2009).

Internet'in ve sosyal medyanın toplumsal hayat üzerindeki olumlu etkilerinin yanında bir de madalyonun öteki yüzü bulunmaktadır. Bunlar, çevrimiçi ortamda zedelenen kişisel mahremiyet, ağ toplumuna erişimi olmayan kesimlerin uğradığı ayrımcılık, internetin küresel demokratikleşme vaadinin sınırıııkları, siber-zorbalık, siber-terörizm, teknik olanaklarla donanmış ve algoritmalar arasına gizlenmiş sansür ve devasa boyutlardaki dezenformasyon (manipülasyon) olarak özetlenebilir (Bauman, 2013; Morozov, 2011; Fuchs, 2011). Özellikle ABD'deki 2016 başkanlık seçimleri ve yine 2016 yılında Birleşik Krallık'ın Avrupa Birliği'nden ayrılmasının oylandığı Brexit referandumu sonrası sosyal medya üzerinden dolaşıma giren "sahte haberler" (fake news) üzerinden seçimlerin manipüle edildiği iddiaları dünya kamuoyunda geniş bir biçimde tartışımaya başlanmış, bu kavram yeni olmamakla birlikte popülerlik kazanmıştır. Hakikat ötesi (post-truth) olarak adlandırılan, "kamuoyu oluşum sürecinde objektif gerçekliğin kişisel inanış ve duygulardan daha az etkili olması" olarak tanımlanan kavram da bu bağlamda tartışmaya açılmıştır (Keyes, 
2004; Post-truth, 2019). Bu görüşe göre yeni iletişim teknolojileri çağında sahte haberler daha fazla ve hızlı biçimde yayılır olmuş ve bu durumun farkında olup sosyal medyadaki haber ortamının güvenilir hale getirilmesinin önemi de artmıştır.

Asında yazılı basının ortaya çıkışından bugüne haberlerin güvenilirliği ve sahte haberlerin toplumsal etkileri tartışma konusu olmuştur. Örneğin, 1835'te New York Sun gazetesi tarafından yayımlanan Ay'da hayat olduğu ile ilgili bir yazı dizisi toplumda yayılarak ciddi ses getirmiştir. Medyanın ideal işlevi, dördüncü kuvvet olarak, yasama, yürütme ve yargı organlarını halk adına denetleyerek ve objektif bir yayıncılık yaparak kamuoyunun doğru bilgiler aracıı̆ı̆ıla oluşmasına katkı yapmaktır (Ceron 2015, s. 488). Ancak 20. yüzyılın ikinci yarısıyla birlikte medyanın ticarileşmesi ve politik etkilerin yoğunlaşması sonucu basının bu ideal işlevi daha çok sorgulanır olmuştur (Norris, 2011). Sosyal medya da hıza ve anındalığa dayanan yapay ağ yapısıyla sahte haberlerin daha çabuk dolaşıma girerek etki kapasitelerinin artmasına neden olmuş, böylece medya yoluyla yapılan dezenformasyon yeni bir boyut kazanmıştır. Özellikle 2016 ABD Başkanlık Seçimleri ve Birleşik Krallık'ın Avrupa Birliği referandumu (Brexit) döneminde, bir takım devletlerin ve grupların sosyal medya üzerinden yanlış bilgileri yayarak seçim sonuçları üzerinde etkili olmaya çalışıkları dünya kamuoyunda hararetli bir biçimde tartışımışı ır (Kucharski, 2016). Bu dönemde yapılan bazı araştırmalar, ABD nüfusunun \%62'sinin haberleri sosyal medyadan almayı tercih ettiklerini ve popüler hale gelen sahte haberlerin Facebook'ta ana-akım medyanın popüler haberlerinden daha fazla dolaşıma girdiğini göstermiştir (Gottfried ve Shearer, 2016; Silverman, 2016, s. 3). Reuters Institute (2018, ss. 108-109) tarafından gazetecilik ve haberlere güven ile ilgili yayınlanan son raporun Türkiye bölümünde de, genel olarak medyadaki haberlerin doğruluğuna olan güvensizliğin oransal olarak ilk defa haberlere duyulan güvenin önüne geçtiği ortaya koyulmuştur (güven \%38 - güvensizlik \%40). Sosyal medyadaki haberlere güven ise \%33 ile genel ortalamanın altında kalmıştır. "Edelman Trust Barometer" (2019, s. 42) raporuna göre de Türkiye'de medyaya duyulan güven geçen seneye göre azalmıştır.

Sosyal medya üzerinden yayılan sahte haber ve manipülasyonlarla mücadele devletler ve örgütler nezdinde de devam etmektedir. Avrupa Parlamentosu tarafından çevrimiçi ortamdaki sahte haber ve dezenformasyon konusunda 2018 yllında kapsamlı bir politika geliştirilmiş, sahte haberlere karşı proaktif bir tutumla çoksesliliğin öne çıkarılması ve kullanıcıların bilinçlendirilmesi için dijital okuryazarlık girişimlerinin başlatılması kararları alınmıştır (Renda, 2018). Yine Avrupa Komisyonu 05.12.2018 tarihinde dezenformasyona karșı bir eylem planı hazırlamış, kamuoyunun sahte haberlerle zarar görmemesi için tüm üye ülkeler bir takım sorumluluklar yüklenmiștir (EEAS Press Team, 2018). Bu çerçevede Alman devleti de sosyal medyadaki sahte haber ve kışkırtmalarla mücadele edebilmek için yasa çıkarma yoluna gitmiş (Netzwerkdurchsetzungsgesetz), nefret söylemi ve sahte haberleri kaldırmayan sosyal medya platformlarına yaptııılar getirmiştir (Müller ve Denner, 2017).

Diğer taraftan, sosyal medyadaki haber ve bilgilerin güvenilirliğine karşı bireysel olarak farkındalık kazanmak ve bilinçlenme yoluyla manipülasyonlarla mü- cadele etme de önem arz etmektedir. Devletlerin, uluslararası kurulusların, sivil toplum örgütlerinin ve çeşitli toplulukların tüm çabaları, bireylerin belirli bir farkındalık düzeyine ulaşmaları, medya mesajlarını doğru şekilde çözümlemeleri, dijital medya okuryazarı olmaları ve karssıarına gelen haberlere karşı eleștirel yaklaşarak teyit çabasına girişmeleri ile birlikte değerlendirildiğinde anlam kazanacaktır.

İlaveten, sosyal medyaya karşı eleştirel yaklaşanların teyit etme çabasının ve sosyal medya paylaşımlarına ilişkin güven düzeylerinin belirlenmesine ilişkin Türkçe bir ölçeğin olmaması da konunun sadece genel çerçevede tanımlanması sorununu beraberinde getirmektedir. ABD'den Avrupa ülkelerine kadar birçok ülkede sosyal medya üzerinden yapılan dezenformasyona karşı adımlar atılırken Türkiye'de bireylerin sosyal medya paylaşımlarına ilişkin güven düzeylerinin ve sosyal medya paylaşımlarının doğruluğunu teyit etme niyetlerinin belirlenmesi de bu bağlamda önem arz etmektedir.

Bu çerçevede mevcut çalışmada, öncelikle, kullanıcıların sosyal medya üzerindeki farklı mecralardan aldıkları haberlere olan teyit/güven düzeylerinin ölçülmesi için bir araç tasarlanması amaçlanmaktadır. Sosyal medya üzerinden profesyonel kimlikleriyle içerik üretenlere (gazeteciler, araştırmacılar, internet gazetecileri, vb.) duyulan güven ile kullanıcı sıfatıyla paylaşım yapanlara (bloggerlar, fenomenler, forum yazarları, vb.) duyulan güven buradaki temel ayrımı oluşturmaktadır. Söz konusu güven düzeylerinin ölçülmesinin yanında, kullanıcıların sosyal medya üzerinden aldıkları haber ve bilgileri kullanmadan ya da paylaşmadan önce herhangi bir araştırma yapıp yapmadıkları ve haber/bilgilerin teyidine dönük farkındalıklarının ölçülmesi hedeflenmiştir.

Bu çerçevede araştırmanın temel soruları şu şekildedir:

1) Sosyal medyada üretilen ya da paylaşılan haberlere ilişkin teyit/ güven ölçeği tasarlamak mümkün müdür?

2) Profesyonel gazeteciler tarafından üretilen haberlerle kullanıcıların ürettiği ya da paylaştığı sosyal medya haberlerine güven arasında anlamlı bir farklılık bulunmakta mıdır?

3) Kullanıılar sosyal medyada karşılaştıkları haberleri paylaşmadan önce ne ölçüde araştırma yapmaktadır?

\section{Literatür Taraması}

Sosyal medya güven/teyit ölçeğinin geliștirilmesi için ifadeler hazırlanırken, literatürde daha önce yapılmış çalışmalardan faydalanılmıştır. İnternet ve sosyal medya üzerinden yayılan bilgi ve haberlere güven konusunda çok çeşitli çalışmalar bulunmaktadır.

Hermida ve diğerlerinin (2012) Kanadalı sosyal medya kullanıcıları üzerinde yaptıkları araştırmada, öğrencilerin diğer yaş ve meslek gruplarına göre daha 
yüksek bir oranda tanınmış (profesyonel) gazetecilerin sosyal medya üzerinden ürettikleri ve paylaştıkları haberlere güvenme eğiliminde oldukları ortaya koyulmuştur. Eğer sosyal medya üzerinden paylaşımı yapan kiși güvenilen bir kanaat önderiyse (tanınmış bir gazeteci, akademisyen ya da araştırmacı), okuyucuların haberin güvenilir olduğuna yönelik inançları da artmaktadır (Stroud ve Lee 2013; Ladd 2011). Mackay ve Lowry'nin (2001, ss. 53-54) Internet gazeteleri, gazetecilerin çevrimiçi blogları ve amatör kullanıcıların bloglarına yönelik kullanıcı güven düzeylerini ölçmek amacıyla, $A B D$ 'deki bir üniversitenin iletişim öğrencileri üzerinde yaptıkları araştırmada ise, gençlerin çevrimiçi ortamda, profesyonel gazetecilere olan güvenlerinin amatör kullanıcıların yaptıkları paylașımlara göre daha düșük seviyede olduğu sonucuna ulașılmıștır. Fletcher ve Park'ın (2017) Avrupa merkezli olarak yaptıkları araştırmada da, genel olarak haberlere güven düzeyi düşük olan kişilerin sosyal medya, bloglar ve/veya basılı olarak yayımlanmayan diğer mecralara haber alma amacıyla daha çok başvurdukları sonucuna varılmıştır.

Turcotte ve diğerlerine (2015, s. 524) göre sosyal medyada karşılaşılan haberin bağlantısı kişinin bir arkadaşı tarafından paylaşıldığında, habere ve haberi paylaşan ilk kaynağa olan güven artmaktadır. Güvenilen bir arkadaşın belirli bir haber kaynağından alıntı yapması, onun da bu habere güvendiği ve haber kaynağının kişinin kendisi ve arkadaşı gibi düşünen insanlara yönelik olduğu algısını güçlendirmektedir. Ayrıca, haberi paylaşan kişinin görüș ve değerleri haberin alııısının görüş ve değerleri ile örtüşüyorsa, sosyal medyadaki enformasyona olan güven duygusu da artmaktadır (Metzger vd., 2010).

Bunun yanında, ana-akım medyada yer alan ve sosyal medyada hızla yayılan dedikoduya dayalı, yanlış bilgi içeren ve tartışmalı haberlere karşı İnternet kullanıcıları çevrimiçi ortamda doğrulama amacıyla ek bilgi arayıșına girebilmektedirler. Ancak teyit amacıyla bașvurulan alternatif çevrimiçi kaynakların kalitesi de tartışmalıdır ve karar alma sürecinde güvenirliği düşük kaynaklardan alınan bilgilerin etkili olması sonucunu doğurabilir (Southwell, 2013; Weeks ve Southwell, 2010). Yine de İnternet ve sosyal medya, sundukları enformasyon ve görüş çeşitliliğiyle araştırma ve/veya teyit olanaklarını çoğaltmaktadır. Bode ve Vraga'nın (2015) araştırmasına göre de sosyal medya, sahte haberlerin hızı biçimde yayılmasına neden olabildiği gibi, bu haberlerin sosyal medya kullanıcıları tarafından hızlı ve basit biçimde teyit edilmesine veya düzeltilmesine olanak sağlayan araçları da sunmaktadır. Ancak bu noktada yaş ile dijital okuryazarlık seviyeleri arasında negatif bir ilişki olduğunu gösteren araştırmalara da rastlanmaktadır. Örneğin, Guess, Nagler ve Tucker'ın (2019) 2016 ABD bașkanlık seçimleri öncesindeki sosyal medya paylașımlarını inceledikleri çalıșmalarında, 65 yaș üzerindeki kullanıcıların genç gruplara göre "sahte haberleri" herhangi bir teyit ihtiyaçı duymadan, yedi kat daha fazla paylaştıkları ortaya koyulmuştur.

Türkiye'de konuyla ilgili yapılan çalışmalara bakıldığında ise, genellikle üniversite öğrencileri ile yapılan ve hangi haber mecralarına daha çok güvenildiği sorusuyla yola çıkan çalışmalar dikkat çekmektedir. Oğuzhan Kavaklı'nın (2010) Ege Üniversitesi öğrencileriyle yaptığı çalışma, yazılı basına güvenin internet gazetelerine göre daha yüksek olduğunu ortaya koymuș; Balcı ve Bekiroğlu (2014) de bu bağlamda benzer sonuçlara ulaşmıştır. Olkun ve Balcı'nın (2016) ve Olkun'un (2017) kurumsal gazetelerin haberleri ile sosyal medya haberlerini karşılaştırdığı çalışmalarında da, sosyal medya haberlerine olan güveninin birincisine göre daha düşük olduğunu ortaya koyulmuştur. Balcı ve Bekiroğlu da (2014) bu çerçevede yaşanan dijital dönüşümlere rağmen kurumsal gazetelerin güven anlamında hala bir adım önde olduğunu tespit etmiștir. Çoban'ın (2015) iletișim fakültesi öğrencileri ile yaptığı çalıșmada da, katıımcıların yarıdan fazlası internet haberlerinin dezenformasyon içerdiğini ifade etmişlerdir. Haber teyidi konusunda ise Kavaklı'nın (2019a) ve Şener'in (2018a) çalışmaları, üniversite öğrencileri arasında haber doğrulama platformlarının bilinirliğinin oldukça düșük seviyede olduğunu ortaya koyarken, Yegen'in $(2018$, s. 117) araștırması da benzer şekilde haber doğrulama sitelerinin yeni filizlendiğini ve az sayıda insanın bu konuda bir fikri olduğunu tespit etmiştir. Şener'in (2018b) konuyla ilgili diğer çalıșmasında ise na-akım medyanın haber doğrulama platformlarını görmezden geldiğine dikkat çekilmiştir. Ayrıca, Kavaklı́nın (2019b) teyit/doğrulama platformlarıyla ilgili araştırmasında, bu mecraların dezenformasyonla mücadelede tek başına yeterli olmayacağı, teyit/doğrulama platformlarına "kurtarıı" misyonu yüklemek yerine "uyarıcı" niteliklerinin ön plana çıkarılması gerektiği sonucuna varılmıştır.

Son olarak, Mavridis'in (2018) Yunanistan'daki Ellinika Hoaxes isimli Facebook grubu üzerinde yaptığı araștırmadan bahsetmek yerinde olacaktır. Araștırmada bu gruba üye olan kullanıcıların büyük çoğunluğunun (\% 79) grupta paylaşılan haberi yeniden paylaşmadan önce bu haberin doğruluğunu farklı kaynaklardan teyit etmeye uğraștıkları ortaya koyulmuştur. Ancak burada dikkat çekici olan husus, söz konusu Facebook grubu üyelerinin sosyal medya üzerinden dolaşıma giren haberleri farklı kaynaklardan doğrulama misyonunu kendilerine yüklemiş olmalarıdır. Bu açıdan, kendine böyle bir haber doğrulama misyonu yüklemeyen sıradan sosyal medya kullanıcılarının sosyal medyadan edindikleri bilgileri çevreleriyle çevrimiçi ve çevrimdıșı ortamda yeniden paylaşmadan önce herhangi bir filtreleme veya doğrulama mekanizması uygulayıp uygulamadıkları önemli bir soru olarak ortaya çıkmaktadır.

\section{Araştırmanın Amacı ve Önemi}

Mevcut çalıșma, kullanıcıların sosyal medya üzerindeki farklı mecralardan aldıkları haberlere olan teyit/güven düzeylerinin ölçülmesi için bir araç tasarlamayı, profesyonel gazeteciler tarafından üretilen haberlerle, kullanıcıların ürettikleri ya da paylaştıkları sosyal medya haberlerine güven arasında anlamlı bir farklılık olup olmadığını ve kullanıcıların sosyal medyada karșılaștıkları haberleri paylașmadan önce ne ölçüde araştırma yaptıklarını incelemeyi amaçlamaktadır.

Alan yazındaki araștırma sonrasında; sosyal medya eylemleri, sosyal medya kullanım nedenleri (Avcı ve Sürücü, 2018), sosyal medya kullanım alışkanlıkları (Altunbaş ve Kul, 2015), sosyal medya kullanımı (Sarıtaş vd., 2017), sosyal medya kullanım bozukluğu (Savcı vd., 2018; Sarıçam ve Adam Karduz, 2018), sosyal medya bağımlıı̆̆ı (Tutgun Ünal ve Deniz, 2015; Fırat ve Barut:, 2018), sosyal medyaya ilişkin 
tutumlar (Otrar ve Argın, 2015) ve haberlerin güvenirliğini etkileyen unsurlar (Balcı ve Bekiroğlu, 2014) konuları üzerine Türkçe geçerli ve güvenilir ölçekler olduğu, ancak sosyal medya teyit/güven düzeyini ölçen bir ölçeğin olmadığı da görülmüştür.

Bu araştırma, sosyal medya teyit/güven konusundaki ölçek eksikliğini gidermenin yanı sıra, sosyal medyadaki kurumsal haber mecraları ile bireysel üretim/paylașımlar arasındaki farkın, duyulan güven temelinde tespiti ve teyit düzeyinin istatistiki olarak ortaya koyması bakımından alan yazındaki boşluğu kapatmayı hedeflediği için önem arz etmektedir.

\section{Araştırmanın Örneklemi}

Araştırmanın evreni Kırklareli Üniversitesi'nde eğitim görmekte olan öğrencilerdir. Ögrenci Işleri Daire Başkanlığı ile gerçekleştirilen toplantı sonrasında üniversitede eğitim gören 26.000 öğrenci bulunduğu öğrenilmiştir. Ölçek geçerlik ve güvenirlik çalışmaları için gerçekleştirilen doğrulayıcı faktör analizine göre; ölçekler için önerilen örneklem büyüklüğü, madde sayısının 20 katı olması gerekmektedir (Kline, 2013, s. 179) ve ölçekte 12 madde bulunduğundan en az 240 kişi ile görüşme yapılması gerekmektedir. Diğer taraftan, bahsi geçen evreni temsil eden örneklem büyüklügünün 379 olduğu tespit edilmiştir (https://www.surveysystem.com/sscalc. htm). Dolayısıyla en az 380 kiși ile görüșme gerçekleștirilmesi planlanmıștır. Universiteden gerekli uygulama izinleri alındıktan sonra üniversite bünyesindeki tüm kampüslerde gönüllülük esasına göre öğrencilere anket uygulaması 3 Aralık 2018 tarihleri ile 4 Ocak 2019 tarihleri arasında gerçekleștirilmiș ve toplam 801 kiși ankete katılmıştır. Ancak, gerçekleştirilen inceleme sonrasında 38 anket formunun eksik olduğu belirlenmiş ve değerlendirme dışı bırakılmış, 763 katılımcının verdiği yanıtlar değerlendirmeye alınmıştır.

\section{Araştırmada Kullanılan Ölçüm Aracı}

Araştırmada kullanılan anket formu 2 bölüm ve 18 ifadeden oluşmaktadır. Buna göre;

İlk bölüm, 2 alt başlıktan oluşmaktadır. İlk alt başlık, katıımcıların demografik özelliklerini belirlemeye yöneliktir ve ilgili bölümde 3 soru bulunmaktadır (cinsiyet, yaş ve aylık harcama). İkinci alt başılık ise sosyal medya platformları ile ilgilidir ve bu bölümde 3 soru bulunmaktadır (sosyal medyada geçirilen süre, en sık kullanılan sosyal medya hesabı ve haberlerin en çok hangi sosyal medya mecrasından alındığı).

İkinci bölüm, sosyal medya güven/teyit düzeyini ölçmek amacıyla yazarlar tarafından geliștirilen ölçektir ve bu bölümde 12 ifade bulunmaktadır. Bu bölümdeki ifadeler ilgili alan yazın taranarak oluşturulmuştur, bu maddelere ve kaynaklara ilişkin detaylar Tablo 1'de incelenebilir. Ayrıca maddeler 5'li Likert tipi değerlendirme ile ölçülmüştür (1 = Hiçbir zaman; 2= Nadiren; 3= Bazen; 4= Sıklıkla; 5= Her zaman) ve ölçeğin uygulamaya hazır hali Ek 1'de görülebilir.
Tablo 1. Sosyal Medya Teyit/Güven Ölçeği Maddeleri ve Kaynakları

\begin{tabular}{|l|l|}
\hline Madde & Kaynak \\
\hline $\begin{array}{l}\text { 1.Basılı olarak dağıtılan gazetelerin } \\
\text { sosyal medya paylaşımlarına güveni- } \\
\text { rim. }\end{array}$ & $\begin{array}{l}\text { Hermida vd., (2012); Stroud ve } \\
\text { Lee, (2013); Ladd, (2011) }\end{array}$ \\
\hline $\begin{array}{l}\text { 2.Internet gazetelerinin sosyal medya } \\
\text { paylaşımlarına güvenirim. }\end{array}$ & $\begin{array}{l}\text { Hermida vd., (2012); Stroud ve } \\
\text { Lee, (2013); Ladd, (2011); Mackay } \\
\text { ve Lowry, (2011) }\end{array}$ \\
\hline $\begin{array}{l}\text { 3.Tanınmış gazetecilerin sosyal med- } \\
\text { ya paylaşımlarına güvenirim. }\end{array}$ & $\begin{array}{l}\text { Hermida vd., (2012); Stroud ve } \\
\text { Lee, (2013); Ladd, (2011); Mackay } \\
\text { ve Lowry, (2011) }\end{array}$ \\
\hline $\begin{array}{l}\text { 4.Kullanıcıların içerik oluşturduğu } \\
\text { mecraların paylaşımlarına güvenirim. }\end{array}$ & $\begin{array}{l}\text { Southwell, (2013); Weeks ve } \\
\text { Southwell, (2010); Mackay ve Low- } \\
\text { ry, (2011); Fletcher ve Park (2017) }\end{array}$ \\
\hline $\begin{array}{l}\text { 5.Sosyal medya fenomenlerinin sos- } \\
\text { yal medya paylaşımlarına güvenirim. }\end{array}$ & $\begin{array}{l}\text { Mackay ve Lowry (2011); Fletcher } \\
\text { ve Park (2017) }\end{array}$ \\
\hline $\begin{array}{l}\text { 6.Arkadaşlarımın/tanıdıklarımın sosyal } \\
\text { medya paylaşımlarına güvenirim. }\end{array}$ & $\begin{array}{l}\text { Turcotte vd., (2015); Fletcher ve } \\
\text { Park (2017) }\end{array}$ \\
\hline $\begin{array}{l}\text { 7.Sosyal medya üzerinden ulaştığım } \\
\text { haberin doğruluğu/güvenilirliği ile ilgili } \\
\text { araştırma yaparım. }\end{array}$ & $\begin{array}{l}\text { Bode ve Vraga, (2015); Mavridis, } \\
\text { (2018) }\end{array}$ \\
\hline $\begin{array}{l}\text { 8.Sosyal medya üzerinden ulaştığım } \\
\text { haberi sosyal medyadaki farklı kay- } \\
\text { naklardan teyit ederim. }\end{array}$ & $\begin{array}{l}\text { Southwell, (2013); Weeks ve } \\
\text { Southwell, (2010); Bode ve Vraga, } \\
\text { (2015); Guess vd., (2019) }\end{array}$ \\
\hline $\begin{array}{l}\text { 9.Sosyal medya üzerinden ulaştığım } \\
\text { bir haberi sosyal medya dışındaki } \\
\text { internet kaynaklarından teyit ederim. }\end{array}$ & $\begin{array}{l}\text { Southwell, (2013); Weeks ve } \\
\text { Southwell, (2010); Bode ve Vraga, } \\
\text { (2015); Guess vd., (2019) }\end{array}$ \\
\hline $\begin{array}{l}\text { 10.Sosyal medya üzerinden ulaştığım } \\
\text { bir haberi internet dışındaki kaynak- } \\
\text { lardan teyit ederim. }\end{array}$ & $\begin{array}{l}\text { Southwell, (2013); Weeks ve } \\
\text { Southwell, (2010); Bode ve Vraga, } \\
\text { (2015); Guess vd., (2019) }\end{array}$ \\
\hline (20)
\end{tabular}

\section{Veri Toplama Süreci}

Anket uygulamaya geçmeden önce 2 ayrı öğrenci grubu ile odak grup görüșmesi gerçekleștirilmiştir. Odak grup görüșmelerinde anketin amacı katılımcılarla paylaşılmış ve soruların anlaşııp anlaşılmadığı, ilave edilmesi ya da 
çıkarılması tavsiye edilen maddelerin olup olmadığı tartışılmıștır. Bu esnada katılımcıların tavsiyesi ile sosyal medya kullanım amaçları ölçeğine 2 yeni ifade eklenmiştir. Odak grup görüşmeleri sürecinde, "kullanıcıların içerik oluşturduğu mecraların paylaşımlarına güvenirim" ifadesi editoryal süreçten geçmeyen paylaşımları anlatacak şekilde "Ekşisözlük" örneğiyle açıklanmış, anketlerin uygulanması sürecinde de araştırmacılar tüm gruplara aynı açıklamayı gerçekleştirmiştir. Ilaveten, yine kullanıcıların içerik oluşturduğu vatandaş gazeteciliği pratikleri odak grup görüşmelerinde gündeme getirilmiş ancak öğrencilerin bu konudaki farkındalıklarının çok düşük seviyede olması nedeniyle ankette bu ayrıma yer verilmemiştir. Anket, odak grup görüşmesi sonrasında uygulamaya hazır hale getirilmiş ve sonrasında ön test işlemi gerçekleştirilmiştir. Ön test sonrasında anket sorularının anlaşıldığı görülmüş ve anket formunda bir değişikliğe gitmeden uygulamaya geçilmesine karar verilmiştir.

\section{Verilerin Analizi}

Verilerin analizi sürecinde iki ayrı istatistik programı kullanılmıştır. Bu programlardan ilki SPSS 22.0 paket programıdır. Bu programda tanımlayıcı istatistiklere ilişkin değerlendirmeler ve açıklayıcı faktör analizine ilişkin analizler gerçekleştirilmiştir. İkinci program ise LISREL 8.71 paket programıdır. Bu program ise doğrulayıcı faktör analizini gerçekleştirmek için kullanılmıştır.

Araştırmaya 438 kadın $(\% 57,4)$ ve 325 erkek $(\% 42,6)$ öğrenci olmak üzere toplam 763 kişi katılmıştır. Katılımcıların yaşları 18 ile 28 arasında değişmekte olup ortalaması 20 yaş (ss 1,94) olarak gerçekleşmiş, aylık harcamaları ise 150 TL ile 2.500 TL arasında değişmekte olup ortalaması 788 TL (ss 453,56) olarak hesaplanmıştır. Katılımcıların sosyal medya platformları ile ilgili görüşleri incelendiğinde; öğrencilerin günde 1 ile 15 saat arasında sosyal medyada zaman geçirdikleri ve günde ortalama 4 saat 16 dakika $(s s 2,52)$ sosyal medyada bulundukları görülmüştür.

Tablo 2. Sosyal Medya Hesapları Kullanımı

\begin{tabular}{|c|c|c|c|c|c|}
\hline \multicolumn{3}{|c|}{$\begin{array}{l}\text { En sık kullanılan sosyal medya he- } \\
\text { sapları }\end{array}$} & \multicolumn{3}{|c|}{$\begin{array}{l}\text { Haberlerin en sık alındığı sosyal medya } \\
\text { hesapları }\end{array}$} \\
\hline & Frekans & Yüzde (\%) & & Frekans & Yüzde (\%) \\
\hline Instagram & 527 & 69,1 & Instagram & 377 & 49,4 \\
\hline Youtube & 120 & 15,7 & Twitter & 148 & 19,4 \\
\hline Twitter & 46 & 6,0 & Youtube & 112 & 14,7 \\
\hline Facebook & 41 & 5,4 & Diğer & 71 & 9,3 \\
\hline Diğer & 29 & 3,8 & Facebook & 55 & 7,2 \\
\hline
\end{tabular}

Tablo 2, sosyal medya hesapları kullanımlarını göstermektedir, buna göre en sık kullanılan sosyal medya hesapları incelendiğinde; sırayla Instagram (527 kişi, \%69,1), Youtube (120 kişi, \% 15,7), Twitter (46 kişi, \%6), Facebook (41 kişi, \%5,4), Tumblr, Google ve Bundle gibi diğer (29 kişi, \%3,8) sosyal medya hesaplarını kullandıkları görülmüştür. Haberlerin ise sırasıyla Instagram (377 kişi, $\% 49,4)$, Twitter $(148$ kişi, \% 19,4), Youtube $(112$ kişi, \% 14,7), Google, Bundle, memurlar.net gibi diğer (71 kiși, \%9,3) ve Facebook $(55$ kiși, \% 7,2) üzerinden alındığı tespit edilmiştir. Buradan hareketle Instagram'ın hem en sık kullanılan hem de en sık haber alınan sosyal medya kaynağı olduğu görülmüştür.

\section{Yapı Geçerliği}

Mevcut araştırma kapsamında ileri sürülen ölçeğin yapı geçerliğine sahip olduğunu göstermek için açıklayıcı ve doğrulayıcı faktör analizi işlemleri gerçekleştirilmiştir (Kalaycı, 2010: 321). Herhangi bir veri setinin açıklayıcı faktör analizine uygun olup olmadığının belirlenmesi amacıyla iki ayrı yöntem kullanılmaktadır. Bu yöntemlerden ilki; Kaiser-Meyer-Olkin (KMO) Örneklem Yeterliliği Testi; ikincisi ise Bartlett Küresellik Testi'dir (Bartlett Test of Sphericity). Buna göre; KMO değerlerinin 0,70'in üzerinde olması ve Bartlett Küresellik Testi'nin p değerinin 0,05'den küçük olması veri setinin faktör analizi için uygun olduğunu göstermektedir (Dülgeroğlu, 2012: 106; Keser vd., 2017: 61).

Tablo 3. KMO ve Bartlett Test Sonuçları

\begin{tabular}{|l|l|l|}
\hline \multicolumn{2}{|l|}{ KMO Örneklem Yeterliliği Testi } & 0,751 \\
\hline \multirow{2}{*}{$\begin{array}{l}\text { Bartlett's Kü- } \\
\text { resellik Testi }\end{array}$} & Yaklaşık Ki-kare & 1907,289 \\
\cline { 2 - 3 } & Serbestlik derecesi & 45 \\
\cline { 2 - 3 } & $\mathrm{p}$ & 0,000 \\
\hline
\end{tabular}

Tablo 3, KMO örneklem yeterliliği ve Bartlett küresellik test sonucunu göstermektedir. Buna göre $\mathrm{KMO}$ değeri 0,70'in üzerindedir ve Bartlett küresellik testinin $p$ değeri $0,05^{\prime}$ den küçüktür. Buradan hareketle veri setinin açıklayıcı faktör analizine uygun olduğunu söylemek mümkündür.

Açıklayıcı faktör analizi çalışmasında faktör türetme yöntemi (extraction method) olarak temel bileşen analizi (principal component analysis) tercih edilmiştir. Döndürme yöntemi (rotation method) olarak da Kaiser Normalleştiricili Varimax (Varimax with Kaiser Normalization) kullanılmıştır. Faktör yükü değerinin 0,45'den büyük olması halinde iyi bir ölçü olabileceği tavsiye edilmiş, en küçük faktör yükü 0,45 olarak belirlenmiş (Bayram, 2004: 136) ve faktör analizi gerçekleştirilmiştir. 
Tablo 4. Varimax Döndürme Yöntemiyle Elde Edilen Faktör Yükleri

\begin{tabular}{|c|c|c|c|c|}
\hline & \multicolumn{3}{|c|}{ Faktör Yükleri } & \multirow{2}{*}{$\begin{array}{l}\text { Madde - } \\
\text { Toplam } \\
\text { Korelas- } \\
\text { yon De- } \\
\text { gerleri }\end{array}$} \\
\hline & Teyit & $\begin{array}{l}\text { Kurumsal } \\
\text { Sosyal Med- } \\
\text { ya Paylaşım- } \\
\text { larına Güven }\end{array}$ & $\begin{array}{l}\text { Bireysel Sos- } \\
\text { yal Medya } \\
\text { Paylaşımları- } \\
\text { na Güven }\end{array}$ & \\
\hline $\begin{array}{l}\text { Sosyal medya üzerinden ulaştığım bir } \\
\text { haberi sosyal medya dışındaki inter- } \\
\text { net kaynaklarından teyit ederim. (F9) }\end{array}$ & 0,846 & & & 0,444 \\
\hline $\begin{array}{l}\text { Sosyal medya üzerinden ulaştığım } \\
\text { haberi sosyal medyadaki farklı kaynak- } \\
\text { lardan teyit ederim. (F8) }\end{array}$ & 0,837 & & & 0,503 \\
\hline $\begin{array}{l}\text { Sosyal medya üzerinden ulaştı̆ı̆ım } \\
\text { haberin doğruluğu/güvenilirliği ile ilgili } \\
\text { araştırma yaparım. (F7) }\end{array}$ & 0,832 & & & 0,458 \\
\hline $\begin{array}{l}\text { Sosyal medya üzerinden ulaştığım bir } \\
\text { haberi internet dışındaki kaynaklardan } \\
\text { teyit ederim. (F10) }\end{array}$ & 0,733 & & & 0,370 \\
\hline $\begin{array}{l}\text { Basılı olarak dağıtılan gazetelerin } \\
\text { sosyal medya paylaşımlarına güveni- } \\
\text { rim. (F1) }\end{array}$ & & 0,841 & & 0,385 \\
\hline $\begin{array}{l}\text { İnternet gazetelerinin sosyal medya } \\
\text { paylaşımlarına güvenirim. (F2) }\end{array}$ & & 0,760 & & 0,355 \\
\hline $\begin{array}{l}\text { Tanınmış gazetecilerin sosyal medya } \\
\text { paylaşımlarına güvenirim. (F3) }\end{array}$ & & 0,650 & & 0,358 \\
\hline $\begin{array}{l}\text { Arkadaşlarımın/tanıdıklarımın sosyal } \\
\text { medya paylaşımlarına güvenirim. (F6) }\end{array}$ & & & 0,805 & 0,316 \\
\hline $\begin{array}{l}\text { Sosyal medya fenomenlerinin sosyal } \\
\text { medya paylaşımlarına güvenirim. (F5) }\end{array}$ & & & 0,791 & 0,334 \\
\hline $\begin{array}{l}\text { Kullanıcıların içerik oluşturduğu mec- } \\
\text { raların paylaşımlarına güvenirim. (F4) }\end{array}$ & & & 0,472 & 0,309 \\
\hline Özdeğer & 2,660 & 1,854 & 1,641 & \\
\hline Açıklanan Varyans & $\% 26,60$ & $\% 18,54$ & $\% 16,41$ & \\
\hline Cronbach's Alpha & 0,830 & 0,667 & 0,651 & \\
\hline Tüm Ölçek Cronbach's Alpha & & 0,705 & & \\
\hline
\end{tabular}

Tablo 4, Varimax döndürme yöntemiyle elde edilen faktör yüklerini göstermektedir. Araștırmacılar sosyal medya teyit/güven ölçeği için 12 madde ile yola çıkmış ancak analizler sonrasında faktör yükü değeri 0,45'in altında olan 2 madde elenmiş ve böylece ölçek 10 ifadeden oluşan hale gelmiştir. Analiz sonuçlarına göre, özdeğeri 1 'in üzerinde 3 faktör bulunmaktadır ve bu faktörler toplam varyansın \%61,55'ini açıklamaktadır. Olçekte bulunan maddelerin faktör yükleri 0,472 ile 0,846 arasında değişmektedir. Madde-toplam korelasyonları ise 0,309 ile 0,503 arasındadır ve tüm ölçeğin içsel tutarlık değeri 0,705 olarak hesaplanmıștır.

\section{Doğrulayıcı Faktör Analizi}

Açıklayıcı faktör analizi sonrasında elde edilen 3 faktörlü modelin doğrulanıp doğrulanmadığını belirlemek amacıyla LISREL 8.71 paket programı ile doğrulayıcı faktör analizi gerçekleştirilmiştir.

LISREL paket programında doğrulayıcı faktör analizinde maddelerin anlamlı olup olmadığını belirlemek için modelin t değerlerine (t-values) bakılmaktadır. Herhangi bir t değerinin 1,96'dan küçük olması, o yolun anlamsız olduğunu, 1,96'dan büyük olması ise, o yolun anlamlı olduğunu (madde ve faktör arasındaki mavi ok, anlamlı ilişkiye işaret etmektedir) göstermektedir (Şimşek, 2007: 86; Taşkın, 2008: 140). Aynı zamanda standartlaștııılmış faktör yüklerinin de 0,50 değerin üstünde olması gerekmektedir (Hair vd., 2010: 708).

Şekil 1. Sosyal Medya Teyit/Güven Ölçeği Standartlaştırılmış Katsayı Çözümleri

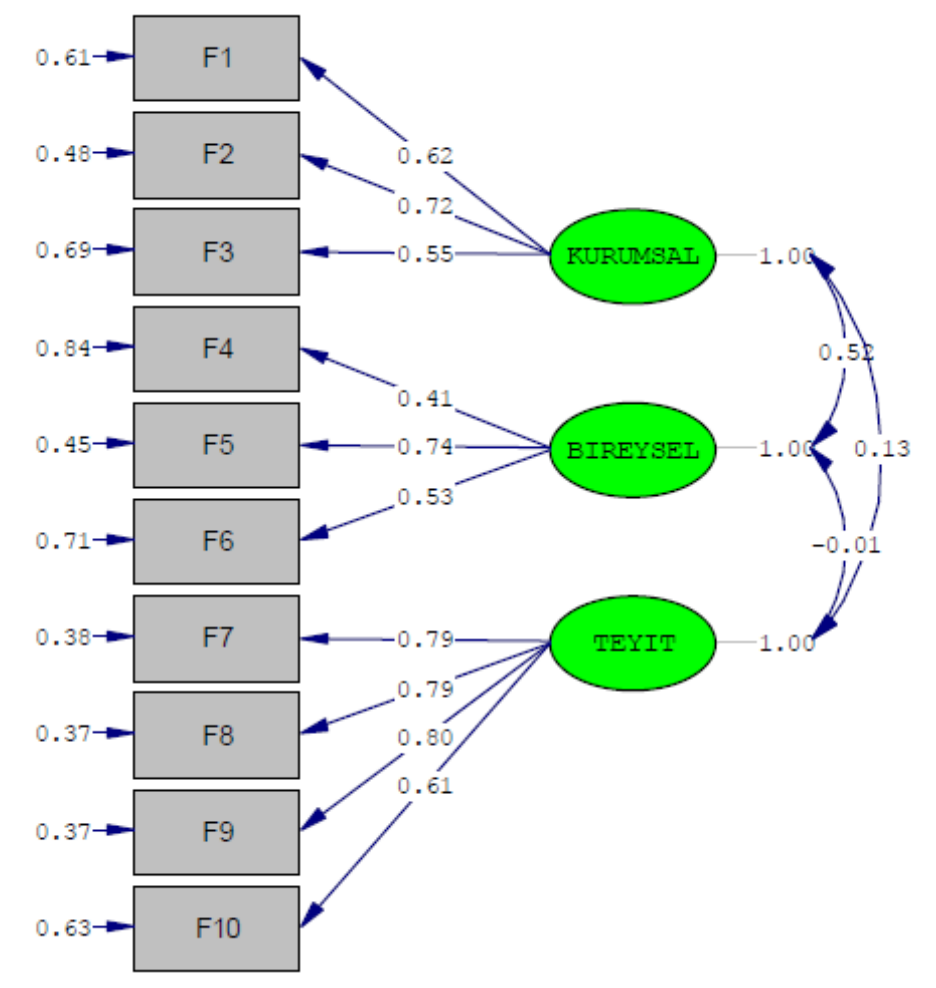

Şekil 1, sosyal medya teyit/güven ölçeğine ilişkin standartlaştırılmış katsayı 
çözümlerini göstermektedir. Buna göre, gerçekleștirilen analiz sonrasında madde ve faktör arasındaki tüm yolların anlamlı olduğu ve bir madde hariç tüm maddelerin standartlaştırılmış faktör yüklerinin 0,50'nin üzerinde olduğu görülmüştür. Esasen standartlaștırılmıs faktör yükü 0,50'nin altında kalan maddelerin modelden çıkarılması önerilmektedir ancak modelin genel yapısının anlamlı olduğu durumlarda 1 maddenin 0,50'nin altında kalmasının kabul edilebilir olduğuna ilişkin görüşler de bulunmaktadır (Sultan vd., 2009: 315: Ertz vd., 2016: 3976; Kurtuldu, 2016: 111). Ayrıca 0,41 standartlaştırılmış faktör yükü değeri, 0,50'nin çok uzağında olmayan bir değerdir. Bu sebeple maddenin (F4) modelde kalmasına karar verilmiştir.

Tablo 5. Sosyal Medya Teyit/Güven Ölçeğine İlişkin Uyum İyiliği Indeksi Değerleri

\begin{tabular}{|c|c|c|}
\hline $\begin{array}{c}\text { Uyum } \\
\text { Iyyiliği } \\
\text { Indeksi }\end{array}$ & $\begin{array}{c}\text { Kabul Edilebilir } \\
\text { Uyum İyiliği İndeksi } \\
\text { Değeri }\end{array}$ & $\begin{array}{c}\text { Sosyal Medya Teyit/Güven Ölçeği } \\
\text { Uyum Iyiliği Indeksi Değerleri }\end{array}$ \\
\hline $\mathrm{X}^{2} / \mathrm{sd}$ & $<5$ & $112.25 / 32=3.50$ \\
\hline $\mathrm{RMSEA}$ & $<0.08$ & 0.057 \\
\hline $\mathrm{NFI}$ & $>0.90$ & 0.95 \\
\hline $\mathrm{NNFI}$ & $>0.95$ & 0.95 \\
\hline $\mathrm{CFI}$ & $>0.95$ & 0.96 \\
\hline $\mathrm{GFI}$ & $>0.90$ & 0.97 \\
\hline $\mathrm{AGFI}$ & $>0.85$ & 0.95 \\
\hline
\end{tabular}

Kaynak: Şimşek (2007); Çelik ve Yılmaz (2013); Kurtuldu (2016)

Tablo 5, sosyal medya teyit/güven ölçeğine ilişkin uyum iyiliği indeksi değerlerini göstermektedir. Gerçekleştirilen analiz sonrasında ileri sürülen sosyal medya teyit/güven ölçeğinin Ki-kare/serbestlik değeri: 3.50; RMSEA: 0.057; NFI: 0.95; NNFI: 0.95; CFI: 0.96; GFI: 0.97 ve AGFI: 0.95 olarak tespit edilmiştir. Elde edilen değerlerin tümü kabul edilebilir uyum iyiliği değerlerinin üzerindedir, buradan hareketle ölçeğin 3 alt faktör ile doğrulandığını söylemek yerinde olacaktır. Diğer bir ifade ile araştırma kapsamında geliştirilen sosyal medya teyit/güven ölçeği öğrenciler için geçerli ve güvenilir bir ölçektir.

Analiz sonucunda elde edilen ilk faktör "teyit" olarak adlandırımıştır ve bu faktörde 4 madde bulunmaktadır. Bu faktör katıımcıların karşılaştıkları sosyal medya paylaşımlarının doğruluğu ile ilgili teyit etme derecesini ölçmektedir ve ilgili ölçeğin içsel tutarlık değeri 0,830 olarak hesaplanmıştır. Herhangi bir ters madde içermeyen ölçekte, ilgili 4 maddenin ortalaması alınmaktadır ve en düşük puan 1, en yüksek puan ise 5 olarak ortaya çıkmaktadır. Ayrıca, katılımcıların teyit puanı arttıkça sosyal medya paylașımlarının teyit etme derecelerinin de arttığını söylemek mümkündür.

Analiz sonucunda elde edilen ikinci faktör "kurumsal sosyal medya paylaşımlarına güven" olarak adlandırımıştır. Bu faktör katılımcıların basılı gazete, internet gazetesi ve tanınmış gazetecilerin sosyal medya paylaşımlarına olan güven düzeyini göstermektedir ve ilgili ölçeğin içsel tutarlık değeri 0,667 olarak hesaplanmıştır. Herhangi bir ters madde içermeyen ölçekte, ilgili 3 maddenin ortalaması alınmaktadır ve en düşük puan 1, en yüksek puan ise 5 olarak ortaya çıkmaktadır. Ayrıca, katıımcıların kurumsal sosyal medya paylaşımlarına güven puanı arttıkça, kurumsal mecralar tarafından gerçekleștirilen paylaşımlara güven düzeyinin arttığı söylenebilir.

Analiz sonucunda elde edilen son faktör "bireysel sosyal medya paylaşımlarına güven" olarak adlandırılmıştır. Bu faktör katıııcıların, sosyal medya fenomenlerinin, kullanıcıların içerik oluşturduğu forumların (örneğin, Ekşisözlük) ve arkadaşlarının sosyal medya paylaşımlarına olan güven düzeyini göstermektedir ve ilgili ölçeğin içsel tutarlık değeri 0,651 olarak hesaplanmıştır. Herhangi bir ters madde içermeyen ölçekte, ilgili 3 maddenin ortalaması alınmaktadır ve en düşük puan 1, en yüksek puan ise 5 olarak ortaya çıkmaktadır. Ayrıca, katılımcıların bireysel sosyal medya paylaşımlarına güven puanı arttıkça, bireyler tarafından gerçekleştirilen paylaşımlara güven düzeyinin arttığı söylenebilir.

Kurumsal ve bireysel sosyal medya paylaşımlarına güven düzeyleri karşılaştırıldığında, bireylerin kurumsal mecralara (ortalama: 3,13 , ss: 0,75 ) (basılı gazete ya da internet gazetesi gibi), bireysel mecralardan (ortalama: 2,66, ss: $0,73)$ (sosyal medya fenomenleri ve arkadaşların paylaşımları gibi) daha fazla güvendikleri (t: 17,549; p: 0,00) sonucu elde edilmiştir. Faktörler ile ilgili ortalamalar incelendiğinde; en yüksek ortalamaya sahip faktörün teyit (ortalama: 3,43 , ss: 0,96 ) olduğu göze çarpmaktadır. Diğer bir ifade ile katılımcılar sosyal medya üzerinden kendilerine gelen paylaşımları teyit etmeden bu bilgilere güvenmemekte ve paylaşmamaktadırlar.

\section{Sonuç ve Tartışma}

Mevcut çalışmanın ilk amacı sosyal medya üzerindeki farklı mecralardan aldıkları haberlere olan teyit/güven düzeylerinin ölçülmesi için bir araç tasarlanmasıdır ve bunun için 763 öğrencinin katıımıyla bir araștırma gerçekleştirilmiștir. Analiz sonrasında "teyit", "kurumsal sosyal medya paylaşımlarına güven" ve "bireysel sosyal medya paylaşımlarına güven" başlıklı 3 faktörlü bir yapının öğrenciler için geçerli ve güvenilir bir ölçek olduğu görülmüștür. Mevcut ölçeğin; sosyal medya paylaşımlarına olan güven düzeyini ve güvenin kurumsal ya da bireysel kaynağa göre nasıl şekillendiğini belirlemek isteyen; ayrıca sosyal medyada gerçekleştirilen paylaşımların gerçek/doğru olarak kabul edilmeden önce teyit edilme düzeyini belirlemek isteyen araştırmacılar tarafından kullanılması önerilmektedir. 10 adet 
ifadeden oluşan form, hızlı cevaplanabilen kısa ve kolay anlaşılır bir yapıya sahiptir.

Ankete katılan üniversite öğrencilerinin en sık kullandıkları ve aynı zamanda en yüksek oranda haber almayı tercih ettikleri sosyal medya platformu Instagram olarak ön plana çıkmaktadır. Temel amacı haber verme olmayan bir kişisel fotoğraf paylaşım bu platformunun bu çerçevede algılanması, sosyal medyanın iletişim ve eğlence amaçlı kullanımı ile haber alma amacının kullanıcı algısında iç içe geçtiğini göstermektedir.

Araştırmanın ikinci amacı profesyonel gazeteciler tarafından üretilen haberlerle, kullanıcıların ürettiği ya da paylaştıkları sosyal medya haberlerine güven arasında anlamlı bir farklıık olup olmadığının belirlenmesidir. Gerçekleştirilen analiz sonrasında; katılımcıların, kurumsal mecralara, bireysel mecralardan daha fazla güvendikleri sonucu elde edilmiştir. Sosyal medyadaki haberlere güven konusunda, sayısal iletişim ağlarında kullanıcı etkileşimi ve içerik üretiminin devasa boyutlara ulaştığı günümüzde bile, profesyonellerce üretilen haberlere ve tanınmış gazetecilerin paylașımlarına olan güvenin yüksek olduğu görülmüștür. Önceki çalışmalara bakıldığında, Oğuzhan Kavaklı'nın (2010) Ege Üniversitesi öğrencileriyle yaptığı araştırmada sonucunda da yazılı basına güveninin \%46.41, internet gazetelere olan güvenin ise \%27.91 düzeyinde olduğu tespit edilmiștir. Balcı ve Bekiroğlu'nun (2014: 213) üniversite öğrencilerinin haberlere güven düzeyleri ile ilgili yaptığı araştırmada da paralel biçimde, haber almak için sıklıkla internet ve sosyal medyayı tercih eden kişilerin bile gazete haberlerini daha güvenilir buldukları sonucu ortaya çıkmıştır. Olkun ve Balcı'nın (2016) ve Olkun'un (2017) kurumsal gazete haberleri ile sosyal medya haberlerine güven düzeyi ile ilgili araştırmaları da benzer şekilde ve birincisi lehine sonuçlar vermiştir. Basılı gazetelerin sosyal medya üzerinden paylaştıkları haberler de bu çerçevede (kurumsal haber üretimi) değerlendirilebileceği gibi, bu durum, yine Balcı ve Bekiroğlu'na (2014) göre iletişim literatüründe iletişim teknolojileriyle bağlantılı yaşanan dönüşümlerin, geleneksel gazete ve gazeteciliği yerinden edemediği tespitiyle paralel bir görünüm arz etmektedir. „Reuters Institute” (2018) tarafından yayınlanan raporun Türkiye bölümünde de benzer şekilde, sosyal medya haberlerine olan güvenin genel olarak medyadaki haberlere duyulan güvene göre daha düşük olduğu görülmektedir.

Sosyal medyada popüler olan ve yoğun etkileşim alan ancak temel amacı haber vermek olmayan "fenomenler" ile kullanıcıların ortaklaşa içerik ürettiği (Ekşisözlük, forumlar vb.) mecralara olan güven ise kurumsal haber mecralarına duyulan güvene göre daha düşük seviyede çıkmıştır. Buradan kurumsal yapıları ile gazetelerin ve kanaat önderi olarak algılanan profesyonel gazetecilerin toplumsal etkilerinin ve güvenilirliklerinin hala "sosyal medya ünlüleri" ne göre daha yüksek olduğu sonucu çıkarılabilir. Kurumsal haberlere duyulan güven ile ilgili sonuçlara daha yakından bakıldığında ise, ilk sırada tanınmış gazetecilerin geldiği, bunu basılı gazetelerin sosyal medya hesaplarının takip ettiği ve son olarak da internet gazetelerinin yer aldığı görülmüştür. Bu sonuçlar da tanınmış profesyonel gazetecilerin toplumda oluşturdukları güven algısı ve "kanaat önderi" olarak kabul edilmeleri eğilimini doğrulamaktadır.
Bireysel kullanıcıların yaptığı sosyal medya paylașımlarına güven ile ilgili yapılan ölçümde dikkat çeken son nokta ise, bu faktörde "arkadaş/tanıdık" paylaşımlarının "sosyal medya fenomenleri" ve "ortak içerik üretilen mecralar"a göre daha fazla güven uyandırdığıdır. Bu sonuç da Turcotte ve diğgerlerinin (2015: 524) araştırmasında ortaya çıkan "sosyal medyada karşılaşılan haberin bağlantıs kişinin bir arkadaşı tarafından paylaşıldığında habere ve haberi paylaşan ilk kaynağa olan güven artmaktadır" sonucu ile uyumlu bir görünüm arz etmektedir.

Araştırmanın son amacı ise kullanıcıların sosyal medyada karşılaştıkları haberleri paylaşmadan önce ne ölçüde araștırma yaptıklarının incelenmesidir. Çoban'ın (2015) iletișim fakültesi öğrencileri ile "internet haberlerine güven" çerçevesinde yaptığı araştırmada, katıımcıların \%59,2'si bu mecraların dezenformasyona yönelik haber ürettiklerini ifade etmişlerdir. Bu çerçevede haberlerin doğruluğu ile ilgili kaygıların bir farkındalığa ve eyleme dönüșme (araștırma/teyit) potansiyeli önemli bir soru olarak ortaya çıkmaktadır. Bu noktada sonuçlar; sosyal medyayı haber alma amacıyla kullanan gençlerin bu konudaki farkındalıklarının ve önlerine gelen haberleri teyit etme reflekslerinin yüksek olduğunu göstermektedir. Kavaklı́nın (2019a) lisans öğrencileri ile yaptığı araştırma da, şüpheli bir haberle karşılaşan kullanıcıların \%91 oranında bu haberi teyit etme çabasına girdikleri, ancak teyit platformları ile ilgili kısıtlı bilgive sahip oldukların göstermiștir. Sener'in (2018a) araștırması da bu durumu destekleyici niteliktedir. Bode ve Vraga'nın (2015) ifade ettikleri gibi, sosyal medya sahte haberlerin hızı biçimde yayılmasına neden olabilmekle birlikte bu haberlerin sosyal medya kullanıcıları tarafından hızlı ve basit biçimde araştırılarak teyit edilmesine olanak sağlayan araçları da sunmaktadır. Araştırmada da paralel şekilde, kullanıcıların sosyal medya üzerinden edindikleri bilgi ve haberleri yine internet ortamında teyit etme eğiliminde oldukları, bu anlamda internet dışı kaynakları daha az kullandıkları görülmüştür. Bu çerçevede internet çağının içinde doğan ve "dijital yerli" (Palfrey ve Gasser, 2011) olarak adlandırılan genç neslin, her zaman doğru araçlara başvurmayabilseler de, sosyal medya üzerinden dolaşıma giren haberlerin sahte olabileceği ve bunların yine internet aracılığıyla teyit edilebileceği yönünde bir farkındalıkları olduğu görülmüştür. Bu farkındalığın günümüz sosyal medya ortamına ve kamuoyunun sağlıklı bilgiler ışığında oluşabilmesi idealine hizmet edebilmesi için de; teyit platformlarının daha yaygınlaşarak tanınır hale gelmesi, bireylerin kendiliğinden bu konularda eyleme geçerek sosyal medyadan elde ettikleri haber ve bilgileri doğrulamaya çalışmaları ve toplum genelinde dijital okuryazarlık eğitim ve seviyesinin arttırımasının faydalı olacağı düşünülmektedir.

\section{Gelecek Araştırmalar}

Mevcut araștırma geçerlik güvenirlik çalıșması yapılan ölçek yalnızca bir üniversitedeki öğrencileri kapsamaktadır, gelecekteki araştırmacılar mevcut ölçeği farklı üniversitelerde eğitim alan öğrencileri de kapsayarak genişletebilir. Ayrıca sosyal medya paylaşımlarında tüm kullanıcıların tutumlarının tespit edilmesi için her yaştan katılımcıyla araştırmalar yapılması, konunun detaylarına ilişkin daha 
fazla bilgi sağlayabilir. Son olarak, sosyal medya haberlerinin doğruluğunun kontrolü/teyidi konusu daha da detaylandırılarak, kullanıcıların bu anlamda hangi dijital ya da çevrimdışı araçlara başvurdukları, haber doğrulama platformlarını ne ölçüde kullandıkları araștırılabilir. Bu anlamda üniversite öğrencileri ve iletișim fakültesi öğrencileri ile çalışabileceği gibi üst yaş grupları ve eğitmenlerin (öğretmen, akademisyen, vb.) konu hakkındaki farkındalık düzeylerini ölçümlemek alana katkı sunabilecektir.

\section{Kaynakça}

Altunbaş, F. ve Kul, M. (2015). Üniversite Öğrencilerinin Sosyal Medya Kullanımı Alışkanlıklarının Ölçümlenmesi: Van Yüzüncü Yıl Örneği. Akademik Bakış Dergisi, 51 (Eylül-Ekim), 414-423.

Atton, C. (2008). Alternative and Citizen Journalism. K. Wahl-Jorgensen ve T. Hanitzsch (Ed.), The Handbook of Journalism Studies içinde (265-278). Routledge.

Avcı, Ö. ve Sürücü, Ç. (2018). Üniversite Öğrencilerinin Sosyal Medya Etkileşimleri: Bartın Üniversitesi Örneği. Karadeniz Uluslararası Bilimsel Dergisi, 40(Kış), 500-513.

Balcı, Ş. ve Bekiroğlu, O. (2014). Medyanın Kritik ve Süreğen Dönemeci: Üniversite Öğrencilerinin Gözünden Medya Haberlerinin Güvenilirliği. Selçuk Üniversitesi Illetişim Fakültesi Akademik Dergisi, 8(2), 192-217.

Bauman, Z. ve Lyon, D. (2013). Akışkan Gözetim. (E. Yılmaz, Çev.). İstanbul: Ayrıntı Yayınları.

Bayram, N. (2004). Sosyal Bilimlerde SPSS ile Veri Analizi. Bursa: Ezgi Kitabevi.

Bode, L. ve Vraga, E. K. (2015). In Related News, that was Wrong: The Correction of Misinformation through Related Stories Functionality in Social Media. Journal of Communication, 65(4), 619-638.

Castells, M. ve Cardoso, G. (2006). The Network Society: From Knowledge to Policy (pp. 3-23). Washington, DC: Johns Hopkins Center for Transatlantic Relations.

Çelik, H. E. ve Yılmaz, V. (2013). Lisrel 9.1 ile yapısal eşitlik modellemesi. Ankara: Anı Yayıncılık.

Ceron, A. (2015). Internet, News, and Political Trust: The Difference between Social Media and Online Media Outlets. Journal of Computer-Mediated Communication, 20(5), 487-503.

Çoban, S. (2015). İletişim Fakültesi Öğrencilerinin İnternet Haberciliğinin Güvenilirliğine Illişkin Tutumları. R. Çelik ve S. Dalgalıdere (Ed.), Yeni ve Geleneksel Medya Okumaları içinde (123-141). İstanbul: İskenderiye Kitap.

Dülgeroğlu, í. (2012). Marka kişiliği, hizmetin kalitesi, hizmete duyulan güven ve sadakat ilişkisi üzerine yapısal eşitlik modellemesi analizi. Yayımlanmamış dokto-

\section{ra tezi, Uludağ Üniversitesi.}

Edelman Trust Barometer. (2019). Global Report. Erișim 22.03.2019. https:// www.edelman.com/sites/g/files/aatuss191/files/2019-03/2019_Edelman_Trust_ Barometer_Global_Report.pdf?utm_source=website\&utm_medium=global_report\&utm_campaign=downloads

EEAS Press Team. (5 Aralık 2018). Action Plan against Disinformation. Erişim 28 Ocak 2019, https://eeas.europa.eu/headquarters/headquarters-homepage/54866/action-plan-against-disinformation_en

Ertz, M., Karataş, F. ve Sarıgöllü, E. (2016). Exploring Pro-environmental Behaviors of Consumers: An Analysis of Contextual Factors, Attitude, and Behaviors. Journal of Business Research, 69(10), 3971-3980.

Fırat, N. ve Barut, Y. (2018). Sosyal Medya Bağımlılığı Ölçeği (SMBÖ)'nin geliştirilmesi: Geçerlik ve Güvenirlik Çalışması. Journal of Human Sciences, 15(4), 2266-2279.

Fletcher, R. ve Park, S. (2017). The Impact of Trust in the News Media on Online News Consumption and Participation. Digital Journalism, 5(10), 1281-1299.

Fuchs, C. (2011). Web 2.0, Prosumption, and Surveillance. Surveillance \& Society. 8(3): 288.

Gottfried, J. ve Shearer, E. (2016). "News Use across Social Media Platforms 2016." Pew Research Center, May 26. http://www. journalism.org/2016/05/26/ news-use-acrosssocial-media-platforms-2016.

Guess, A., Nagler, J. ve Tucker, J., (2019). Less than You Think: Prevalence and Predictors of Fake News Dissemination on Facebook. Science Advances, 5(1).

Günüç, S. (2009). Internet bağımlıık ölçeğinin geliştirilmesi ve bazı demografik değişkenler ile internet bağımlıı̆ı arasındaki ilişkilerin incelenmesi. Yayınlanmamış yüksek lisans tezi, Yüzüncü Yıl Üniversitesi.

Hair, J.F., Black, W.C., Babin, B.J. ve Anderson, R.E (2010). Multivariate data analysis a global perspective. 7th Edition, Global Edition, USA: Pearson.

Hansen, D. ve Shneiderman, B., Smith, M. A. (2011). Analyzing social media networks with NodeXL: Insights from a connected world. Boston: Elsevier

Hermida, A., Fletcher, F., Korell, D. ve Logan, D. (2012). Share, Like, Recommend: Decoding the Social Media News Consumer. Journalism Studies, 13(5-6), 815-824.

Kaplan, A. M. ve Haenlein, M. (2010). Users of the world, unite! The challenges and opportunities of Social Media. Business horizons, 53(1), 59-68.

Kavaklı, N. (2019a). Üniversite Öğrencileri Arasında İnternet Doğrulama/Teyit Platformlarının Kullanımı. Elektronik Sosyal Bilimler Dergisi, 18, 69, 398-411.

Kavaklı, N. (2019b). Yalan Haberle Mücadele ve Internet Teyit/Doğrulama Plat- 
formları. Erciyes İletişim Dergisi. 6(1), 663-682.

Kavaklı, O. (2010). "Gençler Medyaya Güvenmiyor" Erişim 25.01.2019 http:// www.e-psikiyatri.com/GENCLER-MEDYAYA-GUVENMIYOR-7016

Keser, A., Öngen Bilir, B. ve Aytaç, S. (2017). Niceliksel İş Yükü Envanterinin Geçerlik ve Güvenirlik Çalışması. İş-Güç Endüstri İlişkileri Dergisi, 19(2), 55-78.

Keyes, R. (2004). The post-truth era: Dishonesty and deception in contemporary life. Macmillan.

Kline, R. B. (2013). Exploratory and Confirmatory Factor Analysis, Y. Petscher ve C. Schatsschneider, (Ed.), Applied Quantitative Analysis in the Social Sciences ic inde (171- 207). New York: Routledge.

Kucharski, A. (2016). Post-truth: Study epidemiology of fake news. Nature. 540.7634: 525-525.

Kurtuldu, G. (2016). Tüketicilerin Toplulukçuluk Değerlerinin Ölçülmesi Hakkında Bir Ölçek Geçerlemesi. Kırklareli Üniversitesi İktisadi ve İdari Bilimler Fakültesi Dergisi, 5(1): 100-117.

Ladd, J. M. (2011). Why Americans hate the media and how it matters. Princeton, NJ: Princeton University Press.

Mackay, J. ve B., Lowrey, W. (2011). The credibility divide: reader trust of online newspapers and blogs. Journal of Media Sociology, 3(1-4), 39-57.

Mavridis, G. (2018). Fake news and social media: How Greek users identify and curb misinformation online. Yayımlanmamış yüksek lisans tezi, Malmö Üniversitesi.

Metzger, M. J., Flanagin, A. J. ve Medders, R. B. (2010). Social and Heuristic Approaches to Credibility Evaluation Online. Journal of Communication, 60, 413439.

Morozov, E. (2011). The Net Delusion: The Dark Side of Internet Freedom. Jackson, TN: Public Affairs.

Müller, P. ve Denner, N. (2017). Was tun gegen "Fake News"?. Friedrich-Naumann-Stiftung fu $r$ die Freiheit. Berlin: COMDOK GmbH.

Newman, N. (2009). The Rise of Social Media and Its Impact on Mainstream Journalism. Reuters Institute for the Study of Jornalism. Working Paper.

Norris, P. (2011). Democratic deficit: Critical citizens revisited. New York, NY: Cambridge University Press.

Olkun, E. O. (2017). Medya haberlerinin güven algısı üzerinde etkili olan faktörler: Konya örneği. Yayınlanmamış Doktora Tezi, Selçuk Üniversitesi.

Olkun, E.O. ve Balcı, Ş. (2016). Reliability Perception of Media News Among University Students. 2. International Conference on the Changing World and Social
Research, Proceedings Book. 14-16 October. Konya: Palet Yayınları, 779-792.

Otrar, M. ve Argın, F. S. (2015). Öğrencilerin Sosyal Medyaya Illiškin Tutumlarını Belirlemeye Yönelik Bir Ölçek Geliştirme Çalışması. Eğitim ve Öğretim Araştırmaları Dergisi, 4(1), 391-403.

Palfrey, J. G. ve Gasser, U. (2011). Born digital: Understanding the first generation of digital natives. Read HowYouWant. com.

Post-truth. (2019). OxfordDictionaries.com Erişim 22.03.2019. .https://en.oxforddictionaries.com/definition/post-truth

Renda, A. (2018). The legal framework to address "fake news": possible policy actions at the EU level. CEPS Research Report, 2018.

Reuters Institute. (2018). Reuters Institute Digital News Report. Erişim 22.03.2019. http://media.digitalnewsreport.org/wp-content/uploads/2018/06/digital-news-report-2018.pdf?x89475

Rodríguez, C. (2008). Citizens' Media. The International Encyclopedia of Communication.

Sample Size Calculator. Erişim 24 Aralık 2018, https://www.surveysystem.com/ sscalc.htm

Sarıçam, H. ve Adam Karduz, F. F. (2018). Sosyal Medya Kullanım Bozukluğu Ölçeği'nin Türk Kültürüne Uyarlanması: Geçerlik ve Güvenirlik Çalışması. Eğitimde ve Psikolojide Ölçme ve Değerlendirme Dergisi, 9,116-135.

Sarıtaş, A , Korkmaz, i. ve Tunca, M . (2017). Pazarlama Iletişiminde Inovatif Bir Kanal Olarak Sosyal Medyanın Kullanımı: Otomotiv Sektörü Üzerine Bir Araștırma. Uluslararası Iktisadi ve İdari Incelemeler Dergisi, (UPK Ahmet Hamdi İslamoğlu Özel Sayısı), 95-108.

Savcl, M., Ercengiz, M. ve Aysan, F. (2018). Ergenlerde Sosyal Medya Bozukluğu Ölçeği'nin Türkçe Uyarlaması. Nöro Psikiyatri Arşivi, 55, 248-255.

Silverman, C. (16 Kasım 2016). "This Analysis Shows how Fake Election News Stories Outperformed Real News on Facebook." BuzzFeed News. Erişim 22.03.2019 https://www.buzzfeednews.com/article/craigsilverman/viral-fakeelection-news-outperformed-real-news-on-facebook

Şimşek, Ö.F. (2007). Yapısal eşitlik modellemesine giriş. Ankara: Ekinoks.

Solmaz, B., Tekin, G., Herzem, Z. ve Demir, M. (2013). Internet ve Sosyal Medya Kullanımı Üzerine Bir Uygulama. Selçuk İletişim, 7(4), 23-32.

Southwell, B. (2013). Social networks and popular understanding of science and health. Baltimore, MD: Johns Hopkins University Press.

Stroud, N. J. ve Lee, J. K. (2013). Perceptions of Cable News Credibility. Mass Communication \& Society, 16, 67-88. 
Sultan, F., Rohm, A.J. ve Gao, T.T. (2009). Factors Influencing Consumer Acceptance of Mobile Marketing: A Two-Country Study of Youth Markets. Journal of Interactive Marketing, 23, 308-320.

Şener, N.K. (2018a). Gazeteciliğin Geleceğini "Gelecek" Biliyor Mu? Doğruluk Kontrol Merkezlerinin Bilinirliğinin Üniversite Ögrencileri Üzerinde Araștııılması. 16th International Symposium Communication in the Millenium. s. 486-500.

Şener, N. K. (2018b). "Doğruluk Kontrol Merkezi" ve" Yalan Haber" Kavramlarına İlişkin İçeriklerin Medyada Yansımasının Araştırıması. Akdeniz lletisim. s.355373.

Taşkın, Ç. (2008). Pazarlama stratejilerinin oluşturulmasında marka değerinin etkisi ve bir uygulama. Yayımlanmamış doktora tezi, Uludağ Üniversitesi.

Turcotte, J., York, C., Irving, J., Scholl, R. M. ve Pingree, R. J. (2015). News Recommendations from Social Media Opinion Leaders: Effects on Media Trust and Information Seeking. Journal of Computer-Mediated Communication, 20(5), 520-535.

Tutgun-Ünal A. ve Deniz, L. (2015). Development of the Social Media Addiction Scale. Online Academic Journal of Information Technology, 6(21), 51-70.

Van Dijck, J. (2013). The culture of connectivity: A critical history of social media. Oxford: University Press.

Weeks, B. ve Southwell, B. (2010). The Symbiosis of News Coverage and Aggregate Online Search Behavior: Obama, Rumors, and Presidential Politics. Mass Communication and Society, 13(4), 341-360.

Yegen, C. (2018). Doğru Haber Alma Hakkı ve Sosyal Medya Dezenformasyonunu Doğruluk Payı ve Yalansavar ile Tartışmak. Erciyes Illetişim Dergisi, 5(4), 101-121.
Ek 1. Sosyal Medya Teyit/Güven Ölçeği

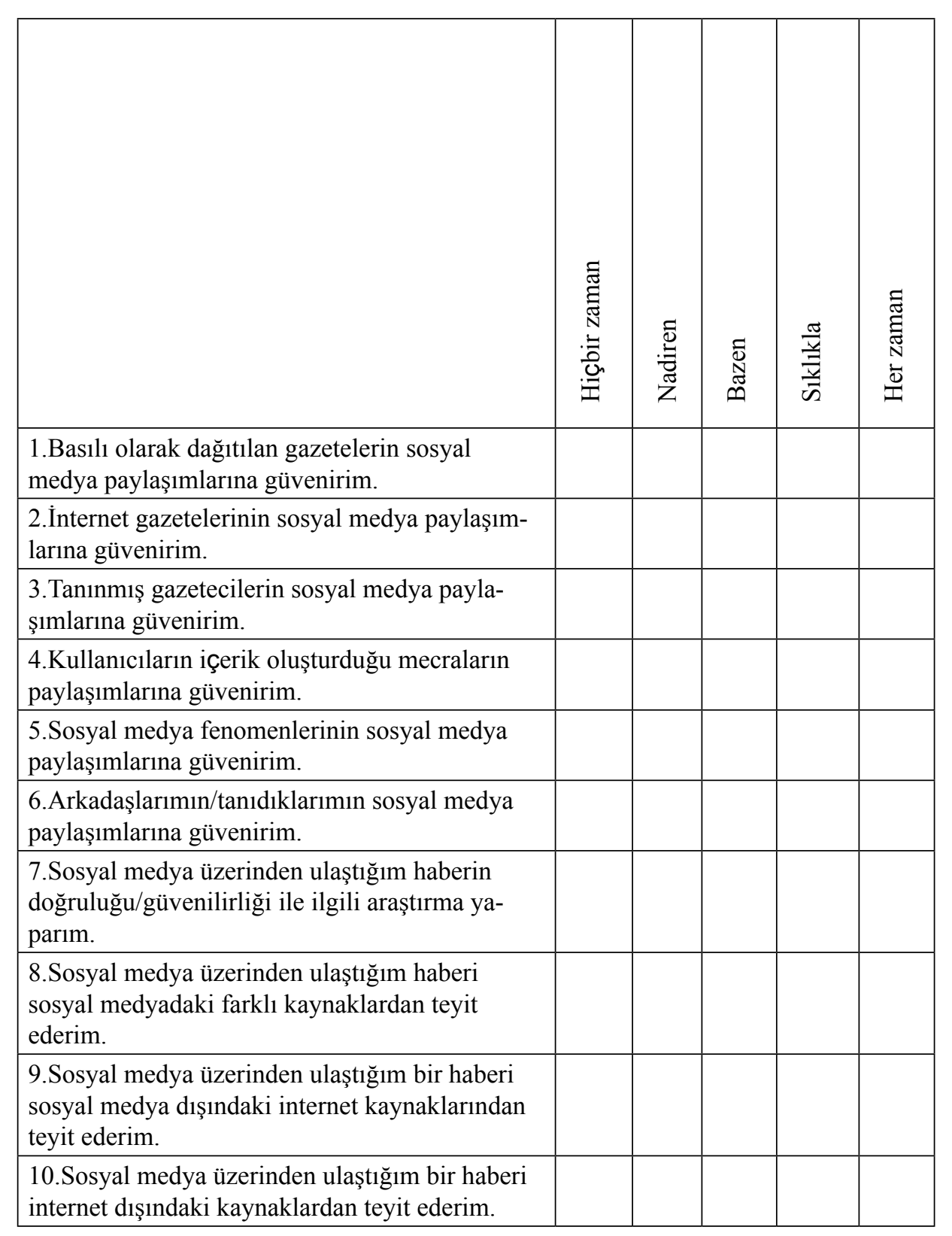


